\title{
Learning Processes and Professional Expectations
}

\author{
Samantha Hacard-Verpoort and J. Tiago Sousa
}

\begin{abstract}
Many of values, knowledge, and forms of identification of the social actors, can be redefined and changed, causing often ruptures with the school learning, because the transition school-work highlights the relationship between the ideal model that represents the social dignity of a profession, his trademark, the symbolic value and the practical model that defining the tasks of everyday life at operational work, which hardly correspond to the creation of the work and tends to accentuate or fade, as a result of both contexts, education and work, because there are contexts where are performed the professional practices.

So, we used the methodology of case study, with data collection techniques, document analysis and semi-structured interview of graduates in HRM, and we used as data processing technique: the content analysis.

The results revealed that the career of the interviewees reflects the data about the role of traineeship in the access to first job and the support to finding employment after completing the degree. We also conclude that school also contributes to instilling a positive spirit on the functioning of the labour market as well as the behavioural rules that potentiate their social integration, like forms of sociability and knowledge networks that remain well beyond the loop created by the imposition of education.
\end{abstract}

Index Terms-Human resources management, employability, career, expectations.

\section{INTRODUCTION}

The access to the labour market corresponds, according to [1], an essential moment of identity construction, being a period of adjustment of expectations and of experimentation during which individuals construct a projection of themselves in the future and build their career anchors [2] decisive for their professional career. In the confrontation with the labour market there is a readjustment between the external and internal career designed by the individual.

In this sense, we will discuss the problems concerning about the importance of school and professional socialization that shape expectations and projections relating to the career of someone. In the following chapter we will present the results of the content analysis of interviews concerning about the professional trajectories, the role of the degree in professional development, the conceptions of respondents about work relations, the access to vocational training and the continuation of studies and finally we will present the main conclusions.

In order to characterize and understand the expectations, projections and professional paths of the graduates in Human

Manuscript received June 4, 2015; revised January 18, 2016.

The authors are with the Escola Superior de Ciências Empresariais, Instituto Politécnico de Setúbal, Portugal (e-mail Samantha.verpoort@live.com.pt).
Resources Management, we use the methodology of case study and exploratory research, having as data collection technique the semi-structured interview applied to graduates in Human Resources Management by the College of Business Administration - Polytechnic Institute of Setubal (ESCE).

\section{THEORETICAL FRAMEWORK}

Far from being an independent entity, the school plays a set of social and symbolic targets, such as to stimulate a positive spirit to students about the functioning of the labour market as well as the behavioural rules that promote the social integration of students and enhancing forms of sociability and knowledge networks, that remain far beyond the bond created with the educational institution and the labour market itself. Allied to this, the school also contributes to the interpretation of the reality of the dominant models and social and political systems that support them [3].

The school socialization is presented as one of the stages of learning and incorporation of values that mark only the beginning of the establishment of professional socialization processes taking place in the workplace, where assimilated values are again reset by future professionals [4]. However the institutions that the individual contacts in the course of their training, results in social and cultural processes, where it becomes relevant in the case of school institution, which was conceived as a space of production and reproduction of knowledge, values, attitudes and symbols, that marks the future of individuals in a structural way, due to their function of developing a new culture through the integration of new generations in the ideal conceived by modern society and to socialize the scientific knowledge [5].

The school socialization and work contexts influence the projection of a career due to the centrality of work in subjects lives [6], where the transition to working life marks a decisive step in the construction of this process [7]. In this transition we consider the underlying concept of the notion of employability as a social integration from the perspective of [1] in which considers a multiplicity of factors that go beyond the purely individual sphere, presenting itself as the result of large and complex social processes that live alongside the experiences that individuals living throughout their multiple and continuous processes of socialization.

So, career development is here understood following the pluralist approach suggested by [8], characterized by a set of structural transformations, in which we highlight the urgent need of flexibility in professional careers. Based on a diverse set of paths, often inconstant, building a career is also based more and more on a growing investment in continuous education, where the prolongation of studies is particularly featured a backdrop of devaluation of diplomas.

In this sense, although the school and work differ as to its 
social function, because both constitute the main social learning spaces, projects and individual aspirations in the acquisition of knowledge, behaviours, values that contribute to the construction of conceptions about the school and work realities.

\section{RESULTS}

The professional practice areas reflect the multiplicity of organizational contexts in which interviewees were entered, as shown in the following table. In this way, we have grouped the nine interviewees as to the specialization of the company where they work according to the typology used by [9]. So, five of them had an immediate access to first job through the traineeship. The professional integration of interviewees reflects a general framework marked by a relative ease of access to the first job. The others four interviewees remained in their organizations where entered during the frequency of the degree. On the one hand, the majority of them had made his career in specialized companies, namely, in which the core business of the company is not focused on Human Resource services and on the other hand, three of them had a pathway in companies specialized in Human Resources services.

TABLE I: CHARACTERIZATION OF THE INTERVIEWEES

\begin{tabular}{|c|c|c|c|c|c|}
\hline $\begin{array}{l}\text { Inter- } \\
\text { viewee }\end{array}$ & 1st job & $\begin{array}{l}\text { Waiting } \\
\text { time: }\end{array}$ & $\begin{array}{l}\text { N. } \\
\text { jobs }\end{array}$ & $\begin{array}{c}\text { Business } \\
\text { Type }^{1}\end{array}$ & $\begin{array}{c}\text { Profess- } \\
\text { ional } \\
\text { area } \\
\end{array}$ \\
\hline E1 & Traineeship & Immediate & 1 & $\mathrm{U}$ & $\begin{array}{c}\text { HR } \\
\text { Coordi-n } \\
\text { ator }\end{array}$ \\
\hline E2 & Invitation & $\begin{array}{c}\text { After } \\
\text { traineeship }\end{array}$ & 1 & $\mathrm{U}$ & VT \\
\hline E3 & Traineeship & Immediate & 2 & $\mathrm{~S}$ & HR \\
\hline E4 & Traineeship & Deferred & 2 & $\mathrm{U}$ & HR \\
\hline E5 & Traineeship & Immediate & 1 & $\mathrm{U}$ & VT \\
\hline E6 & $\begin{array}{c}\text { Worker-Stu } \\
\text { dent }\end{array}$ & - & - & $\mathrm{S}$ & HR \\
\hline E7 & Invitation & $\begin{array}{c}\text { After } \\
\text { traineeship }\end{array}$ & 3 & $\mathrm{U}$ & $\begin{array}{l}\text { HR and } \\
\text { business } \\
\text { function }\end{array}$ \\
\hline E8 & $\begin{array}{c}\text { After } \\
\text { traineeship }\end{array}$ & Immediate & 2 & $S$ & RVCS \\
\hline E9 & $\begin{array}{l}\text { Working } \\
\text { student }\end{array}$ & - & - & $\mathrm{U}$ & IP \\
\hline
\end{tabular}

The Interviewee 6 , recognizes the importance of having taken a degree because: "(...) if I wasn't attending a degree they wouldn't remember me [refers to the people who hired] because I didn't have those requirements "(I6) and she is working on a temporary work agency as Technical Director to perform functions related to Human Resource Management, thus are mainly related to the administrative tasks and therefore she feels that hasn't found a job in the real Human Resource Management area, where she would develop functions related to technical and organizational development, including the evaluation of performance workers, "during my degree and after graduation, my 1st job is still open" and confesses, "(...) Unfortunately, I'm not in a company where I work like Human Resources technician, but only as an

\footnotetext{
${ }^{1} \mathrm{U}$ - Unspecialized / S - Specialized / IP - Industrial production / Process of recognition, validation and certification of skills / VT - Vocational Training / HR - Human Resources.
}

administrative" (I6).

The Interviewee assumes also the responsibility for recruitment and selection of employees for other organizations and does a set of other tasks related to the company's management, "(...) what I do is not just limited to the Human Resources functions, but I'm also Directors secretary". While she was attending the degree in Human Resource Management she says that was one of the difficulties because "(...) I felt that I hadn't the bases"(I6). When she finished her degree she felt confident of their knowledge, however she believes that at the company where she works, she has no opportunity to develop the materials the she learned throughout the course "(...) unfortunately we don't do other processes" but states that "I know where I would find the bases, how could I make a plan, if I didn't have a degree I wouldn't have a clue and I'd be in a panic"(I6). However she decided to join in a master of Human Resource Management and explains "(...) currently with Bologna degrees, in only three years, these degrees are not as valued as degrees in the past by companies, so I thought it best to take [a Master] like an old degree"(I6).

The Interviewee 8 thinks the activities she carried out during the internship were not directly related to what she learned in the course, because they were dealing with RVCC processes, in the first year in which they entered in action: "I was at an internship where we did things I didn't learn in the course, I went to an area a little different "(I8).

After she completed the internship she was worked in a factory and past three months the organization where she held the internship contact her to return and do the same job that she did in the internship, but with precarious employment contract. In this way, she remained 6 years as RVCC professional and after that she applied for a secondary school as a diagnostic technician, to perform the same type of job. She tells us that she decided to change because "I couldn't stand being there, bad environment (...) with any stability, does not allow anything and I heard about the job offers and I'd applied for several schools". She is currently a diagnostic technician at a high school and she is responsible for guiding young and older people for educational and qualification programs.

In terms of education this Interviewee held a postgraduate degree in Training Management and decided to continue because, as stated, the postgraduate degree don't provide any formal qualification and a master's degree could be distinctive in Public Administration careers "(...) I was thinking about investing in my professional life because I was aware that I don 't want to be diagnostic technician for the rest of my life" (I8).

Although he had thought to do a traineeship at the Human Resources department of the company where he worked, the Interviewee 9 tells us: "(...) I didn't had that door opened" (I9) and that impossibility was remarkable for his expectations "(...) I finished my degree and it was the worst thing that happened to me " (I9) - and therefore he has chosen to develop an Organizational Project.

Because he didn't had the opportunity to do an internship in human resource department, he said that the professional return that he expected with the conclusion of his degree didn't meet his expectations and the subsequent completion of 
his degree "(...) part of my goal was to finish, in practical terms, but I didn't have any professional advantage" (I9). This Interviewee has participated in various training courses at the company where he works and he says that his degree showed him the importance of vocational training.

So we can highlight the career of this Interviewee comparing with the others, because it was marked by confrontation with the lack of opportunity at the company where he worked, not having the opportunity to perform in the area of Human Resources, having occurred a gap between the expectations created when he had selected the degree and their conclusion.

The Interviewee 3, was an intern in a HRM consulting firm and faced the curricular internship not only as a requirement for the degree conclusion, but as an opportunity to show his work having had the happiness of General Director seen "(...) some potential, especially in terms of trade and business development and a month later he offered me a business unit to manage "(I3).

In regard to difficulties, were mainly on the performance of business functions, also shows that initially this experience required "(...) more effort about commercial techniques than in technical terms" In this sense, it was necessary to adapt to new functions: "(...) I had to learn to be a recruitment and selection technician". Besides that, the Interviewee has adapted and integrated well in company, because some previous work experience before the degree, precisely in the commercial area. The interviewee appealed to the theoretical knowledge acquired throughout the degree to pursue the activities in the area of recruitment and selection, however said that "(...) all the practical component was learned at work" (I3).

The traineeship turned out to be the 1st job in Human Resources and remained with the company for 2 years. Besides the business group had to manage, was responsible for "(...) to sell a training package to measure (...) and manage the entire process of formation" and accumulate these functions "(...) some internal responsibilities" how to track trainees "curiously in ESCE". He indicate that at some point he "(...) was like number two of the company, for example, when the manager of the Lisbon office were out I was responsible for all office management" highlighting "(...) it was very interesting given my youth at the time"(I3).

After two years he received an offer from another multinational consulting of Human Resources, with a much higher volume of workers in relation to the company that had worked previously and found that it "(...) could give other opportunities, both in terms of growth and in terms of learning above all, I would work with people with many years of experience and knew it would be important to me in professional terms and personal growth and that's what happened"(I3). At new job he began to conduct recruitment in IT area and he said that he had to "(...) start from zero again (...) because the techniques were completely different in many ways" (I3). Although his experience is going well, he tells us that his contract was not renewed and he is "looking for new opportunities."

The Interviewee 5 performed her internship in a municipal company and after completing the internship she was offered to continue through another internship, which only happened after a year. During this period she remained, by her own option, "(...) in the organization working at zero cost " (I5). Today she believes she made the right choice, because after seven years, she's working in the same company, but now with contract. She admits that the linear career path allowed her to have a successful integration in the organization because it's "(...) a different preparation than enter into a new company and not having done this way" (I5) and considers that, for this reason, didn't felt difficulties in their work.

Like Interviewee 4, She confesses that when she graduated she was afraid of not being up to the challenge that is the confrontation with the job market, but despite that she says "When you have a new job to do, you question «I will be able to do it? ", but the truth is that with time things are passed away"(I5). Currently she continues to be in the training area and she's responsible for training office, internal and external, and for the development of school qualifications, at the level of accredited and certification processes. At present she's attending a master's degree in human resource management, because she perceives that is best seen in the labour market and the degree that she took no longer has the same value in the labour market, not ensuring her future employability:

"It seemed to me that as the job market is struggling (...) even though I have a contract for an indefinite period, we know it's not safe as it was a few years ago, it seems to me that if I consolidate knowledge, increase skills, can be an advantage for the future and that's the main reason I came [to the masters] "(I5).

When she started the traineeship (Interviewee 2) she felt more responsibility and tells us that his greatest difficulty was "confrontation with reality" (I2). The Interviewee has developed several activities throughout the traineeship: "(...) my internship was very diverse and rewarding because I had many tasks, because despite being a multinational, were only four in Human Resources Department and the company has 300 employees" (I2).

After the conclusion of his traineeship he ran for an industrial company and he was selected. Although he had only a few months since the completion of his internship until he found employment, he considers that their school is recognized and that gave him a set of skills that facilitated his integration into the job market: "I think ESCE with the set of skills that gave me, which I believe I acquired, I could get a job, with more or less difficulty, so I think that would be an advantage "(I2). In this way, the Interviewee considers that he hasn't had a lot of difficulties in his first job, Although he acknowledged that he felt additional pressure "because if people don't know that I knew what I was doing, they were jeopardize my work, so I think another degree wasn't going beyond that, I don't think I've missed other skills"(I2).

The Interviewee 4 created many expectations for the traineeship and was pleased to hear that would be in the hospital area company because "(...) was put together what I liked most, which was the area of health, with the Human Resources Management"(I4). Despite being happy with the company which would perform the internship, she confesses she was a "little scared because I felt that there was a large requirement level, even in relation to an intern, and when we 
finished the degree, I don't know if you feel that, at the time I felt like I couldn't do anything" (I4).

After she finished the traineeship she worked in banking area, where she made analysis of housing credits. As it was a separate activity in relation to the course that she attended, she had some difficulty regarding to the domain of technical language. However in the case of strictly financial aspects she believes that the course gave him the sufficient knowledge to perform this type of functions: "(...) We don't dominate in any way the technical language, that are things that are very specific, is in at the companies where we can have this notion, but we have financial training and therefore, we can also develop some work in this area" (I4).

After a time working in banking, the company which she made the traineeship invited her to join the team of Human Resources, and she accepted the proposal without any hesitation. Since then she's working in Human Resources Department of a hospital and confesses that their activities are quite varied: "(...) I don't do only what is described in my contract, speaking in terms of work activities" (I4). She performs tasks in the area of Human resource development, mainly in the area of performance evaluation, but also in recruitment and selection, reception and integration, training and all the administrative management of Human Resources. This Interviewee states that would like to pursue studies at the Vocational Training area because perceives that this could be an area to develop in the company: "(...) in the field of training, is an area that I like, and is an area that perhaps It could be developed here otherwise, in particular in the evaluation of the training with metric information's, this is done in a way that maybe in large companies is done differently, perhaps more fashionable and more timely and more efficient, I don't know"(I4).

The Interviewees 5 and 6 , also found it important to continue to study and he enrolled in a master's degree in Human Resources Management because he understands that the post-Bologna degree (3 years) doesn't have the same value in the labour market that the pre-Bologna (5 years). This idea results from the perception that there are new demands from the labour market due to the mass education and the devaluation of diploma, as has been referred to by some authors [10]-[12], and that our Interviewees also referred to:

$"(\ldots)$ «Only accept pre Bologna or masters» (...) when I saw that, well I thought «if this multinational think so, all the others will do also", so I thought, and believed, that I had to give continuity to the degree and with only a 3 years degree I'll have difficulties to accomplish my objective, which is to demonstrate the importance that human resource management has to a company (...) and I want to contribute transmit a good image of Human Resources Management and a personal level, I dream that one day I will also rise my in career "(I2).

The internship of Interviewee 7 was in banking and "didn't go well" Despite having reached the objective of finishing the degree with a good grade he considers that in personal enrichment doesn't come up to his expectations. He assigns responsibility to the difficulty of adjustment because it was a very formal environment and because of the "very specific modus operandi, it is very, very standard procedure" (I7).

When he finished the traineeship he accepted an invitation from a friend to go work on a temporary employment agency and he claims that today was "what I did less attractive but in terms of some personal characteristics, was where I grew more because it was... I treated the recruitment of our customers, but we had to raise the number of customers, for example, much of my working week was seeking new customers, knocking door to door " (I7). However, one of his customers asked him if he was interested in going to work for their company and he decided to accept because he believed that was a qualitative leap in relation to his previous work. After 2 and a half years the company started to not being so well "we started having fewer orders and began to close some factories in Europe" (I7) and he decided to send some resumes to human resources agencies until the opportunity happened, to join a logistics company, where he remains currently.

He's attending a management course for executives, equivalent to a postgraduate degree, because he perceives that it's important to evolve, professionally speaking, and he feels the need to expand his network and to know what's done in other companies. He tells us he want to continue his studies, in particular in business management areas because they are "areas adjacent to Human Resources Management" (I7).

The Interviewee 1 was very anxious to start his internship in a company of automotive sector, because she thought "I didn't know nothing about [indicates the name of the company], zero, what was the company, its business as object, anything" (I1). However the adaptation went well and justify by assigning responsibility to her: "this is my way of living" (I1). In technical terms, she felt some difficulties, but were overcome thanks to the support she had of their Internship Coordinator "my boss and my coordinator at that time, was spectacular, passed me a brutal know-how and even the organization is very open" (I1).

After 3 months of traineeship she continued in the company, through an agreement with the School, and later she held a temporary contract and then also held an outsourcing contract to move to the management of the company. She sees her professional evolution in the company as a "very positive and natural, because first I had an internship, after that I was human resource technician and then my boss came out and I was asked to fill the position of human resources coordination" (I1). Currently she develops a set of new areas at human resources management level, such as performance evaluation, career management and training, as well as all administrative and legal compliance and the entire project management. In addition she still manages the cafeteria and vending machines and she's currently developing the expatriation area. At school level she attended a postgraduate in training management and she expressed the desire to take a master's degree in accounting-financial area because she perceives that this is an area that complements with human resources function:

“(...) I work a lot with my colleagues from the accounting (...) there are instruments that we have to share (...) then there's this whole management, whether you like it or not, but then there is a people-related costs, the number of people, of 
head-count, we got to see the face of the costs we're having, in relation to the volume that we must have. There's a set of activities... I have learned a lot through my colleagues also with my boss because his training base is the financial area "(I1).

\section{CONCLUSION}

Once inserted in the labour market, most of the respondents did not have more than two jobs that can be grouped in companies specializing in Human Resources Management, as opposed to non-specialized companies. In terms of career projection, it tends to settle in strengthening a sense of belonging to the professional field of Human Resource Management, which is held in investment in postgraduate training in Human Resource Management or in areas that with this is articulated.

The stage was for many the first contact with the labour market and the opportunity of facing the profession who wanted to embrace when choosing Human Resources degree. The interviewees have continued working in the same business, choosing to perform an Organizational Project ${ }^{2}$.

So, the career of the respondents appears to reflect a trend evidenced reports on the role of traineeship in access to employment and facility which had finding employment after completing his degree.

The group in question sharing the same basic training in the same institutional context, the unifying role of school socialization tends to be dimmed through the diversity of their career paths and career projection, in its articulation with further study.

There is a clear awareness of a nonlinear relationship between the school knowledge and professional knowledge in the words of our respondents, mentioned by [13], but the company seems to represent the space of recognition and professional socialization, as the role of contexts work assumes importance in redefining their expectations and career structures and results in the centrality of work today, a source of professional fulfilment, but also personal and which is based on an individual, collective and interactive dimension that depends on the optimization of dynamic training taking place in that context, emphasized as seen through vocational training strategies and further education developed by the Respondents. Having regard to the [6], we are facing the school reproductive effect on the valuation of the study extension to find related to the cultural effect of the School, which develops an aptitude for constant acquisition of knowledge.

In this sense, the respondents seem to value continuing vocational training provided by the companies, because the face as a condition for professional development in the company or outside of it, in fact, its value derives from their career prospects. In addition to the training, further education, which we realized, it is seen as a driving process of professional development and support to mobility, such as changing area or even specialty, according to training strategies that induce the course of careers.

\section{REFERENCES}

[1] R. Mauritti, "Impact of social backgrounds in higher education paths," IV Portuguese Congress of Sociology, Coimbra, 2000.

[2] E. Schein. (1990). Career anchors and job/role planning: The links between career pathing and career development. MIT Sloan School of Management. [Online]. Available: http://dspace.mit.edu/bitstream/handle/1721.1/2315/SWP-3192-2260 3401.pdf

[3] B. S. Santos, By Alice's Hand, Social and Political in Post-modernity, Afrontamento, Porto, 1994.

[4] D. Tavares, "School and professional identity - The case of cardiopneumology technicians," Colibri, Lisbon, 2007.

[5] R. Canário, "Training and change in the health field," Training and Work Situations, Porto Editora, Porto, 1997, pp. 117-146.

[6] C. Dubar, Socialization - Building Social and Professional Identities, Porto Editora, Porto, 1997.

[7] N. Alves, School and Work: Attitudes, Projects and Trajectories, Young Portugueses of Today, Celta Editora, 1998.

[8] A. Almeida, M. Marques, and N. Alves, "Careers: New ways to labor relations," presented at IV Portuguese Congress of Sociology, Coimbra, 2000.

[9] $I Q F$, "People management: Tendencies, skills and training," 2006.

[10] N. Alves, Youth and Employability, Educa, Lisbon, 2008.

[11] M. Alves, N. Alves, and M. Chaves, "Employability and reasons for entry and re-entry into higher education. A starting point for a theme opened," Sociology Problems and Practice, vol. 69, pp. 99-118, 2012.

[12] R. Canário. (September 2007). School / family / community for educational society. Seminary School / Family / Community. [Online]. pp. 104-140. Available www.cnedu.pt/files/pub/EscolaFamilia/7-Conferencia.pdf

[13] R. Canário. (October 2006). Learn without being taught. The strategic importance of non-formal education. Education in Portugal (1986-2006). [Online]. pp. 159-206. Available: http://espacoseducativos.files.wordpress.com/2007/05/a-educacao-em -portugal-1986-2006-alguns-contributos-de-investigacao.pdf

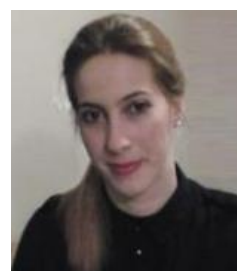

Samantha Hacard-Verpoort has a degree and a masters in human resource management for the College of Business Administration, Polytechnic Institute of Setubal. She is currently professor in the same school and teaches courses related to the field of human resource management. Before that, she worked at Stanton Chase International and Critical Software. She is $\mathrm{PhD}$ student at Universidade Nova de Lisboa and published several articles in the area of education, organizational communication and professional training.

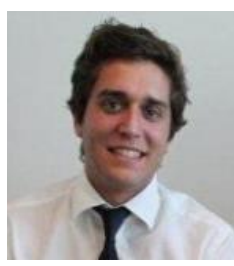

José Tiago Sousa has a degree and a masters in human resource management and work at Lisnave Shipyards, being responsible for vocational training of the organization. He is currently a $\mathrm{PhD}$ student at Universidade Nova de Lisboa.

\footnotetext{
${ }^{2}$ Alternative mode to traineeship for students workers.
} 